\title{
USE OF BROCCOLI (Brassica oleracea italica) LEAVES POWDER TO PRODUCE FRESH PASTA
}

\author{
R. P. CEMIN, A. O. RIOS, R. C. S. THYS, S. H. FLÔRES e R. RECH \\ Universidade Federal do Rio Grande do Sul, Instituto de Ciências e Tecnologia de Alimentos \\ E-mail para contato: rafacemin@cpovo.net; rrech@ufrgs.br
}

\begin{abstract}
Broccoli is a vegetable usually consumed by the population as a source of bioactive compounds such as carotenoids and tocopherols. However, the broccoli processing mainly uses the flowers, remaining the leaves and stalks as by-products. This work used dried broccoli leaves powder to enrich fresh pasta, and compared its sensory and technological characteristics with pasta enriched with spinach powder. The levels of lutein and $\beta$-carotene in broccoli flower and leaves were also quantified. Lutein and $\beta$-carotene analysis on broccoli leaves showed, $2.512 \mathrm{mg} / 100 \mathrm{~g}$ and $1.554 \mathrm{mg} / 100 \mathrm{~g}$ respectively. Regarding to the technological characteristics, broccoli pasta showed better results for cooking loss $(6.36 \%)$ and water uptake $(183.9 \%)$ when compared to the spinach one. The broccoli and spinach pasta showed overall acceptance of $74.4 \%$ and $81.1 \%$, respectively, higher than $70 \%$, that is the minimum required for the indication of the product to the market test.
\end{abstract}

\section{INTRODUCTION}

Several epidemiological studies associates the intake of carotenoids with a decreased risk of several degenerative diseases in humans (Schünemann et al., 2002), so green leafy vegetables, which are rich in bioactive compounds, have been widely studied (Krinsky and Johnson, 2005). The broccoli is a highly nutritious plant, rich in vitamins, carotenoids and minerals, but usually only the flowers are used by consumers and industry, therefore about 75 $\%$ of the plant is discarded, resulting in waste of nutrients, since the vitamin content in the leaf can be 2 to 4 times higher than in the broccoli flower (Wu et al., 1992).

The waste of fruit and vegetables that are usually discarded by the industry could be used as alternative sources of nutrients, improving the nutritional value of processed foods and supplying dietary deficiencies (Pereira, 2003).

Consumers are becoming aware of the composition and the optimal intake of essential vitamins, minerals and phytonutrients contained in fruits and vegetables, to maintain a healthy diet and prevent diseases (Arscott and Tanumihardjo, 2010).

One strategy to increase the intake of vegetables is their incorporation into pastas, as dried vegetables powder or vegetable pulps (Silva et al., 2012), as the incorporation of dried leaves of spinach and amaranth (Borneo and Aguirre, 2008). The quality of the cooked pasta can be expressed in terms of viscosity, firmness and cooking loss, as well as by water absorption, swelling, cooking loss and susceptibility to breakage (Manser, 1981). 
This study used dried broccoli leaves to enrich fresh pasta and described the changes in the physicochemical and cooking proprieties of pasta, compared to standard spinach pasta.

\section{MARERIALS AND METHODS}

\subsection{Broccoli}

Broccoli were acquired in a local food distributor center (Ceasa, Porto Alegre, Brazil). The leaves and flowers were selected considering the absence of visible injury and infections and also color uniformity. Before drying, the leaves were washed and disinfected sanitized with chlorine solution (200 ppm sodium hypochlorite, $15 \mathrm{~min}$ ).

Drying of broccoli parts (leaves, buds of flowers or stalk) was performed in a tray dryer at $60{ }^{\circ} \mathrm{C}$. The samples were distributed uniformly into a perforated basket and the weight loss was measured every 20 min to constant weight (approximately $2 \mathrm{~h}$ ).

\subsection{Carotenoid analysis}

Carotenoid content in broccoli leaves, buds or stalks was determined on fresh and dried samples by high performance liquid chromatography (HPLC). The carotenoid extract was prepared according to the method of Mercadante and Rodriguez-Amaya (1998). The pigments were extracted with acetone and saponified with $10 \% \mathrm{KOH}$ in methanol, overnight at room temperature. After the removal of the alkali, the extract was concentrated in a rotary evaporator (Fisatom, Uberlândia, Minas Gerais, Brazil) $\left(T<35^{\circ} \mathrm{C}\right)$, transferred to an amber flask, dried under a nitrogen stream, and stored at $-18^{\circ} \mathrm{C}$ for further analysis.

A HPLC system Waters Alliance ${ }^{\circledR}$ E2695 with photodiode array detector (PDA) Waters 2998 and software Empower was used. The mobile phase was water:methanol:tertmethyl butyl ether (MTBE) (JTBaker, Cas. Number 1634/04/04, purity 99,96 \%, EUA) starting at 5:90:5, reaching 0:95:5 in $12 \mathrm{~min}, 0: 89: 11$ in $25 \mathrm{~min}, 0: 75: 25$ in $40 \mathrm{~min}$ and finally 0:50:50 after a total of $60 \mathrm{~min}$, with a flowrate of $1 \mathrm{~mL} / \mathrm{min}$ at $33^{\circ} \mathrm{C}$ (Zanatta, 2007). Prior to use, the mobile phase was filtered through a $0.45 \mathrm{~nm}$ filter and degassed using u ltrasonic agitation (Unique, model USC 1400). The same was done with the extract for subsequent injection.

The carotenoids were quantified using standard curves of lutein $(1-65 \mathrm{mg} / \mathrm{L}$, purity $>95$ $\%$, Indofine Chemical Company Inc., USA), and $\beta$-carotene $(5-50 \mathrm{mg} / \mathrm{L}$, purity $>93 \%$, Sigma Chemical, USA). The results were expressed in milligrams per $100 \mathrm{~g}$ of dry sample.

\subsection{Pasta production}

The fresh pasta was produced using wheat flour (Farinha de Trigo Tipo 1 - Orquídea, Tondo SA, Brazil), cold water, salt, pasteurized whole egg (Fleisheggs - Fleischmann, Brazil) and broccoli leaves powder or spinach powder (Tutti Secchi, Brazil) according to the formulation shown in Table 1. The particle size of both green powders was 35 mesh.

All dried components of the formula (flour, green powder and salt) were mixed in a mixer with extruder AME 07/15 at low speed until a uniform mix was achieved before the 
addition of pasteurized eggs and water. Water was added gradually and mixed at low speed until the dough reached an adequate consistency for extrusion. Final water concentration was $(34 \pm 1) \mathrm{g} / 100 \mathrm{~g}$ of total mixture. The pasta was extruded in Fettuccine format and cut in 30$\mathrm{cm}$ length pieces. The samples were stored at $-18{ }^{\circ} \mathrm{C}$, after being packed in plastic packaging, for further analysis. Two batches of each formulation were produced.

Table 1 - Green pasta formulations

\begin{tabular}{lcc}
\hline Ingredients & broccoli pasta $(\mathbf{g})$ & spinach pasta $(\mathbf{g})$ \\
\hline Flour (wheat) & 1000 & 1000 \\
Broccoli leaves powder & 250 & - \\
Spinach leaves powder & - & 250 \\
Pasteurized liquid eggs & 160 & 160 \\
Salt & 20 & 20 \\
\hline
\end{tabular}

\subsection{Physicochemical analysis}

Moisture content was performed by weight loss at $105^{\circ} \mathrm{C}$. Water activity $\left(a_{w}\right)$ of the pasta samples was determined at $25{ }^{\circ} \mathrm{C}$ using portable water activity meter. Pasta was broken into small pieces immediately before water activity measurement.

Color determination was carried out on the surface of pasta samples before and after cooking using a portable colorimeter following the color system of the CIE- $L^{*} a^{*} b^{*}$, where the $L^{*}$ value (brightness) ranges from black (0) to white (100), the chroma $a^{*}$ value ranges from green (-60) to red (+60) and the chroma $b^{*}$ value ranges from blue (-60) to yellow $(+60)$. The color difference $(\Delta E)$ of pasta samples before and after cooking was calculated using Equation 1. Three punctual color determinations were performed on each pasta sample.

$$
\Delta E=\sqrt{(\Delta a)^{2}+(\Delta b)^{2}+(\Delta L)^{2}}
$$

\subsection{Pasta cooking quality}

The optimal cooking time, cooking loss and water uptake in cooked pasta were determined using the American Association of Cereal Chemists Official Methods 16-50 and 16-51 (AACC, 2000).

Pasta samples $(10 \mathrm{~g})$ were broken into 5 -cm pieces and cooked in $170 \mathrm{~mL}$ of boiling tap water. The optimal cooking time was taken when the white core disappeared after squeezing the sample between two glass plates. After cooking, fettuccini was drained for $5 \mathrm{~min}$. The drained and cooking water were collected and mixed. A sample was dried at $105{ }^{\circ} \mathrm{C}$ until constant weight. The cooking loss $(C L)$, expressed as percentage of raw pasta.

Cooked fettuccini was rinsed with water for $30 \mathrm{~s}$, drained for 1 min to expel the remaining water and weighed. The water uptake $(W U)$ in cooked pasta, expressed ratio between final and initial sample weights. 


\subsection{Sensory analysis}

The sensory evaluation of the pasta samples was carried out by a panel of 50 untrained judges between 18 and 60 years old using an acceptance test. The criteria for the recruitment of the participants were that they regularly ate fresh pasta, had no food allergies (especially to eggs and gluten), and were available and willing to participate on the test day. The samples were identified with random three-digit code numbers and were served in polyethylene plastic dishes in random order. The test was conducted in an environmentally controlled sensory laboratory with partitioned booths, illuminated with fluorescent bulbs. The chambers were free from environmental elements that could distort normal perception.

The acceptance of attributes such as appearance, color, flavor, aroma, texture and overall acceptability were evaluated using a hedonic scale of 9 points. The study had the permission of the University Ethical Committee (Protocol n: 459216) and the participants were informed of every detail of the scope of the present research.

\section{RESULTS AND DISCUSSION}

\subsection{Carotenoid content}

The $\beta$-carotene content of broccoli leaves and flowers was evaluated before and after drying process (Table 2). Results show an increase of $250 \%$ and $187 \%$ of the $\beta$-carotene in dried leaves and dried flowers, respectively. Previous studies already reported an increase of $\beta$-carotene from heat-treated vegetables when compared to the raw ones, due a change in the structural matrix and favoring the extraction (Rodriguez-Amaya, 1997). The lutein content, after drying, showed increase of $300 \%$ and $332 \%$ in the leaves and flowers respectively.

Table 2 - Amount of $\beta$-carotene and lutein in broccoli

\begin{tabular}{lcccc}
\hline & \multicolumn{2}{c}{$\boldsymbol{\beta}$-carotene $(\mathbf{m g} / \mathbf{1 0 0} \mathbf{g})$} & \multicolumn{2}{c}{ Lutein $(\mathbf{m g} / \mathbf{1 0 0} \mathbf{g})$} \\
& raw & dried & raw & dried \\
\hline Leaf & $1.55 \pm 0.20$ & $5.39 \pm 0.01$ & $2.51 \pm 0.29$ & $10.05 \pm 0.65$ \\
Flower & $0.72 \pm 0.25$ & $2.07 \pm 0.69$ & $0.72 \pm 0.34$ & $3.15 \pm 0.77$ \\
\hline
\end{tabular}

The content of $\beta$-carotene and lutein, in six different cultivars of broccoli, ranged from 0.48 to $1.13 \mathrm{mg} / 100 \mathrm{~g}$ and 0.41 to $1.02 \mathrm{mg} / 100 \mathrm{~g}$, respectively (Singh et al., 2007). Another study performed on fresh broccoli from Taiwan, reported an average content of $1.72 \times 10^{-2}$ $\mu \mathrm{mol} / \mathrm{g}$ of lutein and $1.66 \times 10^{-2} \mu \mathrm{mol} / \mathrm{g}$ of $\beta$-carotene (Kao et al., 2012). In the study performed by Nachtigall et al. (2007) the levels of lutein in broccoli were between 0.76 $\mathrm{mg} / 100 \mathrm{~g}$ and $1.84 \mathrm{mg} / 100 \mathrm{~g}$. Our study analyzed the lutein and $\beta$-carotene content of the different broccoli parts, whereas in previously published studies usually the values are not discriminated by flower, stalk or leaf. The broccoli leaves showed carotenoid content higher than the flower, therefore its addition in food mixtures may be beneficial to human health. 


\subsection{Physicochemical analysis and cooking quality determinations}

The results of the physicochemical analysis and cooking quality determinations performed in the samples of broccoli and spinach pasta are shown at Table 3.

For both samples, the optimum cooking time was around 4 min and the other cooking characteristics (solid loss and water uptake) were evaluated at this standard cooking time. Chillo et al. (2007) found that the decrease of the gluten network facilitates the diffusion of water through the matrix of the dough, reducing the time that water needs to reach the center of the dough during cooking.

Table 3 - Results of physicochemical analysis and cooking quality of green pasta

\begin{tabular}{lccc}
\hline Analisys & Broccoli pasta & Spinach pasta & $\boldsymbol{p}$-value \\
\hline Water activity & $0.944 \pm 0.001$ & $0.913 \pm 0.001$ & $<0.0001$ \\
Moisture content & $33.7 \pm 1.5$ & $32.6 \pm 0.3$ & 0.2188 \\
Color $(\Delta E)$ & $11.9 \pm 1.0$ & $4.0 \pm 1.9$ & 0.0003 \\
Cooking time $(\min )$ & 4 & 4 & - \\
Cooking loss $(\%)$ & $6.36 \pm 0.62$ & $8.62 \pm 0.53$ & 0.0015 \\
Water uptake $(\%)$ & $183.9 \pm 0.7$ & $182.6 \pm 0.7$ & 0.0162 \\
\hline
\end{tabular}

The water activity of both samples allows the growth of some bacteria and fungi, making necessary the use of cooling to prevent the proliferation of microorganisms during storage and transport (Jay, 2005). The moisture of both samples is within the range allowed by Brazilian law for fresh pasta (maximum of $35 \%$ ) (ANVISA, 2005).

The cooking loss is widely used as an indicator of pasta quality (low cooking loss indicates high pasta quality) and is considered to be strongly related to a proper gluten network development during dough formation.

According to the criteria of Hummel (1966), pastas of high quality show cooking loss up to $6 \%$ of solids, cooking loss between $6 \%$ and $8 \%$ means a medium quality pasta, and higher than or equal to $10 \%$ are characteristic pastas of poor quality. Donnelly, (1979) also considers $8 \%$ as the maximum acceptable value for the loss of solids in water cooking. Compared to spinach pasta, the broccoli pasta showed lower cooking loss, indicating a better quality pasta.

The broccoli and spinach pastas presented water uptake around $183 \%$. Fresh pastas with water uptake values between $200 \%$ and $300 \%$ are considered of high quality (Hummel, 1966).

The color differential parameter) indicates how stable to cooking are the color pigments. The broccoli pasta presented higher $\Delta E$, indicating a lower stability of its pigments. In the study by Wood (2009), the parameter of color differential for dry pasta with $25 \%$ fortification with chickpeas showed an average of $27.21 \%$. Have the work of Carini et al., (2010), using semolina durum wheat showed a good result in this parameter in different ways of mixing the ingredients obtained 1.9 and $3.0 \%$, indicating good color stability. 
The color parameters $L^{*} a * b *$ for raw and cooked pasta are presented in Table 4 . The spinach pasta showed higher green hue and higher brightness compared to the broccoli one. Both pastas lost green hue and gained yellow hue after cooking. The high intensity of green color of the fresh pasta is a highly desired feature in the product, because this is one of the most significant characteristic of visual appeal for acceptance of color fresh pasta. There were significant difference before and after cooking in parameter $b^{*}$ of both pasta and the parameter $a^{*}$ only in the pasta of broccoli.

Tabela 4 - Color parameters for the raw and cooked pasta

\begin{tabular}{|c|c|c|c|}
\hline \multirow{2}{*}{ Parameter } & \multicolumn{2}{|c|}{ Broccoli pasta } & \multirow{2}{*}{$p$-value } \\
\hline & raw & cooked & \\
\hline$L^{*}$ & $30.06 \pm 2.55$ & $31.09 \pm 1.63$ & 0.5228 \\
\hline$a^{*}$ & $-2.33 \pm 0.29$ & $-3.03 \pm 0.37$ & 0.0239 \\
\hline \multirow[t]{3}{*}{$b^{*}$} & $9.59 \pm 1.03$ & $21.11 \pm 0.86$ & $<0.0001$ \\
\hline & \multicolumn{2}{|c|}{ Spinach pasta } & n-value \\
\hline & raw & cooked & $p$-value \\
\hline$L^{*}$ & $34.53 \pm 1.72$ & $34.09 \pm 1.34$ & 0.7017 \\
\hline$a^{*}$ & $-5.26 \pm 0.76$ & $-4.41 \pm 0.58$ & 0.1380 \\
\hline$b^{*}$ & $14.24 \pm 2.36$ & $17.69 \pm 1.33$ & 0.0475 \\
\hline
\end{tabular}

The broccoli pasta showed a lower cooking loss and no significant difference for water uptake and cooking time, compared with spinach pasta. However cannot be classified as high quality pasta. Better results on cooking quality will probably be achieved decreasing the amount of green flour of the mixture. In the study by Chang and Martínez Flores (2004) pastas made using Triticum Aestivum wheat were classified as pasta of excellent quality, with the patterns of loss of solids established by Hummel (1966).

\subsection{Sensory analysis}

Sensory analysis (Table 5) showed a good acceptance for both pastas and concluded that the replacement is pleasant to the taste of the people and improves the nutritional intake. Both broccoli and spinach formulations could be marketed, since they showed acceptance of 74.4 $\%$ and $81.1 \%$, respectively.

Table 5 - Result of sensory analysis

\begin{tabular}{lccc}
\hline Attribute & Broccoli pasta & Spinach pasta & P value \\
\hline Appearance & $6.6 \pm 1.4$ & $7.3 \pm 1.3$ & $<0.0001$ \\
Color & $6.8 \pm 1.4$ & $7.5 \pm 1.4$ & 0.0004 \\
Aroma & $6.9 \pm 1.5$ & $7.4 \pm 1.3$ & 0.0170 \\
Texture & $6.9 \pm 1.2$ & $7.0 \pm 1.5$ & 0.9369 \\
Flavor & $6.3 \pm 1.6$ & $7.4 \pm 1.1$ & 0.0003 \\
Overall acceptability & $6.7 \pm 1.1$ & $7.3 \pm 1.0$ & 0.0019 \\
\hline
\end{tabular}


In a study conducted with different formulations of gnocchi containing stalks of broccoli there was a good sensory acceptance and also enhancing the nutritional value (Malucelli et al., 2009). Another study of the use of crop residues, including stalks of broccoli, for preparation of pies, sensory results also showed positive, proving the benefit of using waste for the manufacture of foods rich in nutrients (Souza et al., 2007).

\section{CONCLUSION}

The addition of broccoli leaves powder in fresh pasta was presented as a good alternative for the production of green pastas, showing more than $70 \%$ of sensory approval, minimum required to display the product for market testing and future marketing. Broccoli pasta also showed similar cooking characteristics and pasta of quality when compared to spinach pasta. In future studies it would be interesting to make the quantification of nutrients and carotenoids in the pasta of broccoli to assess the product's benefits to health. It can also be tested other amounts of broccoli leaves powder to improve the overall standards of acceptance and cooking.

\section{REFERENCES}

AACC. Method 16-50. 2000.

ANVISA, Resolução RDC n²63 de 22 de setembro de 2005 - Regulamento técnico para produtos de cereais, amidos, farinhas e farelos. 2005.

ARSCOTT, S. A.; TANUMIHARDJO, S. A. Carrots of Many Colors Provide Basic Nutrition and Bioavailable Phytochemicals Acting as a Functional Food. Compr. Rev. Food Sci. Food Saf., v. 9, n. 2, p. 223-239, 2010.

BORNEO, R.; AGUIRRE, A. Chemical composition, cooking quality, and consumer acceptance of pasta made with dried amaranth leaves flour. LWT--Food Sci. Technol., v. 41, n. 10, p. 1748-1751, 2008.

CARINI, E. et al. Effect of different mixers on physicochemical properties and water status of extruded and laminated fresh pasta. Food Chem., v. 122, n. 2, p. 462-469, 2010.

CHANG, Y. K., MARTÍNEZ FLORES, H. E.. Qualidade tecnológica de massas alimentícias frescas elaboradas de semolina de trigo durum (T. durum L.) e farinha de trigo (T. aestivum L.). Food Sci. Technol. (Campinas), v. 24, p. 487-493, 2004.

CHILLO, S. et al. Effect of carboxymethylcellulose and pregelatinized corn starch on the quality of amaranthus spaghetti. J. Food Eng., v. 83, n. 4, p. 492-500, 2007.

DONNELLY, B. J. Pasta products: Raw material, Technology, Evaluation. Macaroni J., v. 61, n. 1, p. 6, 1979.

HUMMEL, C. Macaroni products: manufacture, processing and packing. London, Food Trade P. 1966

JAY, J. M. Modern food microbiology. New York: Van Nostrand Reinhold, 1992.

KAO, F. J. et al. Effects of Chinese domestic cooking methods on the carotenoid composition of vegetables in Taiwan. LWT-Food Sci. Technol., v. 46, n. 2, p. 485-492, 2012.

KRINSKY, N. I.; JOHNSON, E. J. Carotenoid actions and their relation to health and disease. 
Mol. Aspects Med., v. 26, n. 6, p. 459-516, 2005.

MAlUCElli, M., NOVEllo, D., ANDO, N., ALMEIDA, J. M., FREITAS, A. R. Avaliação e composição nutricional de nhoque tradicional enriquecido com farinha de resíduo de brócolis (Brassica Oleracea var. itálica). Aliment. Nutr., v.20, n.4, p. 553-560, 2009.

MANSER, J. Optimale Parameter fuer die Teigwarenherstellung am Beispiel von Langwaren. Getreide, Mehl Brot, v. 35, p. 75-83, 1981.

MERCADANTE, A. Z.; RODRIGUEZ-AMAYA, D. B. Effects of Ripening, Cultivar Differences, and Processing on the Carotenoid Composition of Mango. J. Agric. Food Chem., v. 46, n. 1, p. 128-130, 1998.

NACHTIGAlL, A., STRINGHETA P. C., FIDELIS, P. C., NACHTIGALL, F. M. Determinação do teor de luteína em hortaliças. B.CEPPA, v. 25, n. 2, p. 181-192, 2007.

PEREIRA, G. I. M. S. Avaliação química da folha de cenoura visando ao seu aproveitamento na alimentação humana. Cienc. Agrotecnol., v .27, n. 4, p. 852-857, 2003.

RODRIGUEZ-AMAYA, D. B. Carotenoids and food preparation: the retention of provitamin A carotenoids in prepared, processed and stored foods. Arlington, John Snow Inc. 1997.

SCHÜNEMANN, H. J., McCANN, S., GRANT, B. J., TREVISAN, M., MUTI, P., FREUDENHEIM, J. L. Lung Function in Relation to Intake of Carotenoids and Other Antioxidant Vitamins in a Population-based Study. Am. J. Epidemiol., v. 155, n. 5, p. 463471, 2002.

SILVA, E., SCHOLTEN, E., VAN DER LINDEN, E., SAGIS, L. M. C. Influence of swelling of vegetable particles on structure and rheology of starch matrices. J. Food Eng., v. 112, n. 3, p. 168-174, 2012.

SINGH, J., UPADHYAY, A. K., PRASAD, K., BAHADUR, A., RAI, M. Variability of carotenes, vitamin C, E and phenolics in Brassica vegetables. J. Food Compos. Anal., v. 20, n. 2, p. 106-112, 2007.

SOUZA, P. D. J., D. NOVELlO, J. M. ALMEIDA, AND D. A. QUINTILIANO, 2007, Análise sensorial e nutricional de torta salgada elaborada através do aproveitamento alternativo de talos e cascas de hortaliças, Aliment. Nutr., v.18, n.1, p.55-60, 2007.

WOOD, J. A. Texture, processing and organoleptic properties of chickpea-fortified spaghetti with insights to the underlying mechanisms of traditional durum pasta quality. J. Cereal Sci., V. 49, n. 1, p. 128-133, 2009.

WU, Y.; PERRY, A. K.; KLEIN, B. P. Vitamin c and $\beta$-carotene in fresh and frozen green beans and broccoli in a simulated system. J. Food Qual., v. 15, n. 2, p. 87-96, 1992.

ZANATTA, C. F. MERCADANTE, A. Z. Carotenoid composition from the Brazilian tropical fruit camu-camu (Myrciaria dubia). Food Chem., v. 101, n. 4, p. 1526-1532, 2007. 